\title{
MULTIELEMENT ANALYSIS OF LAKE BAIKAL WATER BY HR-ICP-MS
}

\author{
Dwinna Rahmi, Yanbei Zhu, Tomonari Umemura, and Hiroki Haraguchi* \\ Department of Applied Chemistry, Graduate School of Engineering, Nagoya University \\ Furo-cho, Chikusa-ku, Nagoya 464-8603, Japan \\ *e-mail: haraguch@apchem.nagoya-u.ac.jp
}

\begin{abstract}
Twenty-four elements in Lake Baikal water were determined by HR-ICP-MS instrument, where two river water reference materials, JSAC 0302 and JAC 0032, were applied to verification of the accuracy of analysis. The concentrations of the analyte elements covered a range of nine orders of magnitude, from approximately $17 \mu \mathrm{g} \mathrm{mL}^{-1}$ of Ca to less than $2-3 \mathrm{pg} \mathrm{mL}^{-1}$ of Cs. Lake Baikal water samples from various water depths showed similar chemical compositions to one another. The distribution of the elements in Lake Baikal water was compared with that in Lake Biwa water, which is the largest lake in Japan. Despite the general similarity in elemental distribution of the two lakes, $\mathrm{U}$ and $\mathrm{Li}$ were relatively enriched in Lake Baikal water while $\mathrm{Y}, \mathrm{Mn}$, and As were relatively enriched in Lake Biwa. Based on the enrichment factor of elements in lake waters, the relative low Li concentration in Lake Biwa water was suggested to be an anomaly, which might be attributed to the deposition of organic deposit that enriched Li.
\end{abstract}

Keywords : multielement analysis, lake water, HR-ICP-MS

\section{EFERENCES}

1. T. Kira, Compact-size Edition of Data book of world Lake Environments: Asia and Oceania, Miyagawa Printing Co., Ltd, 1995.

2. R. F. Weiss, E. C. Carmack, and V. M. Koropalov, Nature, 349: 665, (1991).

3. K. K. Falkner, C. I. Measures, S. E. Herbelin, J. M. Edmond, and R. F. Weiss, Limnol. Oceanogr., 36: 413, (1991).

4. K. K. Falkner, M. Church, C. I. Mesures, G. LeBaron, D. Thouron, C. Jeandel, M. C. Stordal, G. A. Gill, R. Mortlock, P. Froelich, and L.-H. Chan, Limnol. Oceanogr., 42: 329, (1997).

5. A. N. Suturin, L. F. Paradina, V. N. Epov, A. R. Semenov, V. I. Lozhkin, L. L. Petrov, Spectrochim. Acta, 58(B): 277, (2003).

6. E. I. Grosheva, G. N. Voronskaya, M. V. Pastukhove, Aquatic Ecosystem Health \& Management, 2001, 3: 229.

7. M. Sugiyama, N. Kimura, and Y. Harita, Transactions of The Research Institute of Oceanochemistry, 14: 77, (2001).
8. T. I. Fujinaga, Y. Sohrin, K. Isho, Chemistry of Marine and LakeInvestigated by Trace Element, Kyoto University Press. (in Japanese), 2005.

9. H. Haraguchi, Bull Chem Soc Jpn., 72: 1163, (1999).

10. H. Haraguchi, J. Anal. At. Spectrom., 19: 5, (2004).

11. Y. Zhu, A. Itoh, and H. Haraguchi, Bull Chem Soc Jpn., 78: 107, (2005).

12. T. Yabutani, S. Ji, F. Mouri, A. Itoh, K. Chiba, and H. Haraguchi, Bull. Chem. Soc. Jpn., 73: 895, (2000).

13. A. Itoh, T. Nagasawa, Y. Zhu, K-H. Lee, E. Fujimori, and H. Haraguchi, Anal. Sci., 20: 29, (2004).

14. Y. Zhu, R. Hattori, D. Rahmi, S. Okuda, A. Itoh, E. Fujimori, T. Umemura, and $\mathrm{H}$. Haraguchi, Bull. Chem. Soc. Jpn., 78: 1970, (2005).

15. S. R. Taylor, and S. M. Mclennan, The continental crust: its composition and evolution, Blackwell Scientific Pub., 1985.

16. B. S. Kamber, A. Greig, and K. D. Collerson, Geochim. Cosmochim. Acta., 69: 1041, (2005). 
17. A. Itoh, K. Iwata, K. Chiba, and $\mathrm{H}$. Haraguchi, Bull. Chem. Soc. Jpn., 73: 121, (2000).

18. A. Itoh, T. Nagasawa, Y. Zhu, K-H. Lee, E. Fujimori, and H. Haraguchi, Anal. Sci., 20: 29, (2004).
19. P. Henderson, Rare earth element geochemistry, Elsevier Science Pub., 1984.

20. H. Sakurai, New knowledge about 111 elements, Kodansha.(in Japanese), 1997. 